\title{
ANALISA TUMPAHAN CRUDE PALM OIL (CPO) DI TELUK BAYUR SUMATERA BARAT, 28 SEPTEMBER 2017
}

\author{
ANALYSIS OF CRUDE PALM OIL SPILL AT BAYUR BAY \\ WEST SUMATERA ON SEPTEMBER 28TH, 2017 \\ Herdiana Mutmainah ${ }^{1}$, Ilham ${ }^{1}$, Try Altanto ${ }^{1}$, Hadi $^{2}$, \& Rizki Anggoro Adi ${ }^{1}$ \\ ${ }^{1}$ Loka Penelitian Sumber Daya dan Kerentanan Pesisir, Balitbang KP, KKP \\ ${ }^{2}$ Balai Pengelolaan Sumberdaya Pesisir dan Lautan, KKP \\ Komp. PPS Bungus, Jl. Raya Padang Painan KM 16, Telp/Fax. 0751-751458. Teluk Bungus. Padang. \\ Sumatera Barat. Indonesia. \\ e-mail : herdianamute77@gmail.com
}

Diterima tanggal: 14 Juni 2019 ; diterima setelah perbaikan: 11 November 2019 ; Disetujui tanggal: 25 April 2020 DOI: http://dx.doi.org/10.15578/jkn.v15i1.7853

\begin{abstract}
ABSTRAK
Degradasi kualitas perairan dapat disebabkan oleh berbagai hal salah satunya tumpahan minyak. Walaupun merupakan minyak nabati, tumpahan Crude Palm Oil (CPO) atau minyak mentah kelapa sawit pada beberapa kasus di Indonesia menimbulkan degradasi kualitas air laut yang cukup signifikan dan berdampak buruk terhadap biota laut. Penelitian ini bertujuan untuk memaparkan peristiwa terjadinya tumpahan CPO di Teluk Bayur pada 28 September 2017 pkl. 09.30 WIB dan langkah-langkah yang dilakukan oleh seluruh pihak baik masyarakat, perusahaan dan beberapa instansi terkait dalam menangani tumpahan CPO serta menganalisa dampak tumpahan CPO terhadap perairan dan pulau-pulau kecil sekitarnya disertai alternatif solusi. Metode yang digunakan wawancara, survey literatur, dan survey primer berupa pengamatan sebaran tumpahan CPO dengan GPS dan drone; serta pengukuran kualitas air laut baik menggunakan alat WQC TOAA maupun pengukuran di laboratorium. Hasil analisa menunjukkan tumpahan Crude Palm Oil (CPO) di Teluk Bayur telah menyebabkan degradasi kualitas lingkungan perairan pada beberapa parameter seperti temperatur permukaan laut 30,5 ${ }^{\circ}$; pH: 5,7; DO: 0,55-3,89 mg/L; BOD: 0,39-0,48 mg/L; COD: $121-180 \mathrm{mg} / \mathrm{L}$ dan minyak lemak: 1,4-6,6 mg/L. Karakteristik CPO berwarna jingga seperti mentega, tekstur licin. CPO yang bercampur air laut dan pasir memiliki berat jenis $3,75 \mathrm{gr} / \mathrm{cm}^{3}$. Pada beberapa kasus, selain naiknya temperatur dan $\mathrm{pH}$ tetapi juga BOD, COD dan turbiditas serta menurunkan DO dan TDS. Tumpahan CPO berdampak negatif pada ekosistem dan biota laut seperti Mangrove, udang Windu, kepiting, coral dan lain-lain. Hal ini disebabkan karena gumpalan dan lapisan CPO menutupi permukaan perairan sehingga mengganggu penetrasi sinar matahari dan proses respirasi dan fotosintesis tanaman laut. Diperlukan kewaspadaan dan mitigasi bencana tumpahan minyak untuk mengurangi resiko degradasi lingkungan. Beberapa cara yang dapat digunakan untuk mengurangi kadar minyak atau tumpahan CPO seperti Oil Boom, Oil sponge, tanaman air Azolla folliculoid hingga bakteri tertentu jenis Bacillus dan Geobacillus.
\end{abstract}

Kata kunci : CPO, degradasi, kualitas lingkungan perairan.

\begin{abstract}
The spill of Crude Palm Oil (CPO) at Bayur Bay on September 28th, 2017 decresed the quality of sea water. Although CPO is a kind of vegetable oil but in some cases in Indonesia, it decreased the marine quality and brought significant impact to marine biota. This research aims to describe how the CPO spill over the Bayur Bay and the coordinaion from all sectors to handle the CPO spill; how to analyse the impact of CPO spill to small islands water and the solutions. The method using interview, literature study and primary survey by observation using GPS and drone; and also water sampling using WQC TOAA and laboratory to analyse the water quality. The result showed that temperature at $30.5^{\circ} \mathrm{C} ; \mathrm{pH}: 5.7 ; \mathrm{DO}: 0.55-3.89 \mathrm{mg} / \mathrm{L} ; \mathrm{BOD}: 0.39-0.48 \mathrm{mg} / \mathrm{L} ; \mathrm{COD}$ : 121-180 mg/L and fat oil: 1.4-6.6 mg/L. The characteristic of CPO is like butter,with smooth texture. CPO that contains sea water and sand has specific gravity $3.75 \mathrm{gr} / \mathrm{cm}^{3}$. CPO spill has wide impact to the ecosystem especially to Mangrove, shrimp, crabs, corals, etc. CPO spill covered water surface that disturb the respiration and photosyntesis process. It need awareness and mitigation to reduce the risk of degradation. Some solutions to
\end{abstract}


absorb the oil spill through not only by engine equipment such as Oil Boom and Oil Sponge but also natural water plant i.e Azolla folliculoid and bacterial i.e Bacillus and Geobacillus.

Keywords: $C P O$, degradation, water environment quality.

\section{PENDAHULUAN}

Pada tanggal 28 September 2017 pkl. 09.30 WIB terjadi kebocoran pipa tangki timbun minyak sawit PT. Wira Inno Mas yang terletak di kawasan Pelabuhan Teluk Bayur, Sumatera Barat. Sekitar 50 Ton Crude Palm Oil (CPO) tumpah ke laut dan sebagian mengendap di pesisir sekitar Teluk Bayur. CPO atau minyak sawit kasar (kelapa sawit, Elaeis guineensis Jacq.) adalah minyak yang diekstrak dari daging buah kelapa sawit (mesokarp) dan mengandung lemak alkohol, metil ester, dan asam lemak. CPO terdiri dari unsur padat dan cair. Unsur padat berupa asam lemak jenuh (miristat 1\%; palmitat 45\%; stearat 4\%) sedangkan unsur cair berupa asam lemak tidak jenuh (oleat 39\%; linoleat 11\%). Sifat fisik CPO adalah berwarna orange/jingga, bau khas, berbentuk pasta dengan kadar air $3,7589 \times 10-3 \mathrm{~mL} / \mathrm{g}$; indeks bias 1,4692; massa jenis $0,8948 \mathrm{gr} / \mathrm{mL}$; larut pada eter dan aseton; sedikit larut dalam etanol dan tidak larut dalam air payau (Deffense, 1985 dalam Setyono \& Soetarto, 2008). Massa jenis CPO adalah $0,8948 \mathrm{gr} / \mathrm{mL}<1 \mathrm{gr} /$ $\mathrm{mL}$ (massa jenis air) sehingga sifatnya mengapung di air.

Keterangan gambar (a). Aktivitas nelayan dan pihak perusahaan dalam mengumpulkan material $\mathrm{CPO}$ dari laut ke dalam kolam pelindo (b). Masyarakat mengumpulkan material CPO dan dikumpulkan untuk kemudian menunggu pihak perusahaan mengangkut, (c), Pembersihan material CPO di Pulau Sinyaru (d). Rapat antara instansi pemerintah dengan pihak perusahaan terkait rencana penanggulanan tumpahan CPO.

\section{BAHAN DAN METODE}

Metode yang digunakan adalah dengan melakukan ground truthing menggunakan GPS secara purposive sampling untuk mengamati titik-titik sebaran CPO dan WQC TOAA untuk pengukuran parameter kualitas air, botol Nansen untuk pengambilan sampel air, sediment grab untuk sampel sedimen dan saringan untuk mengambil sampel CPO. Analisa terhadap kualitas air, CPO dan sedimen menggunakan metode gravimetri, granuler dan spektometri yang dilakukan di Labkes Dinkes Prov.Sumbar dan Lab Mekanika Tanah UNP, Padang. Pengamatan terhadap sebaran tutupan tumpahan CPO di laut dilakukan secara visual dan foto udara menggunakan drone.

\section{HASIL DAN PEMBAHASAN}

.Sisa tumpahan CPO yang terbawa arus tersebar dan berbentuk gumpalan tak beraturan dengan ukuran bervariasi, dari butiran kecil hingga besar berdiameter sekitar $0,5 \mathrm{~mm}$ hingga $15 \mathrm{~cm}$, dengan rata-rata ukuran serpihan $2,5 \mathrm{~cm}$. Temperatur laut adalah $30,5^{\circ} \mathrm{C}$ dengan pH 5,7. Suhu melebihi standar baku mutu laut untuk coral dan lamun namun dibawah standar baku mutu
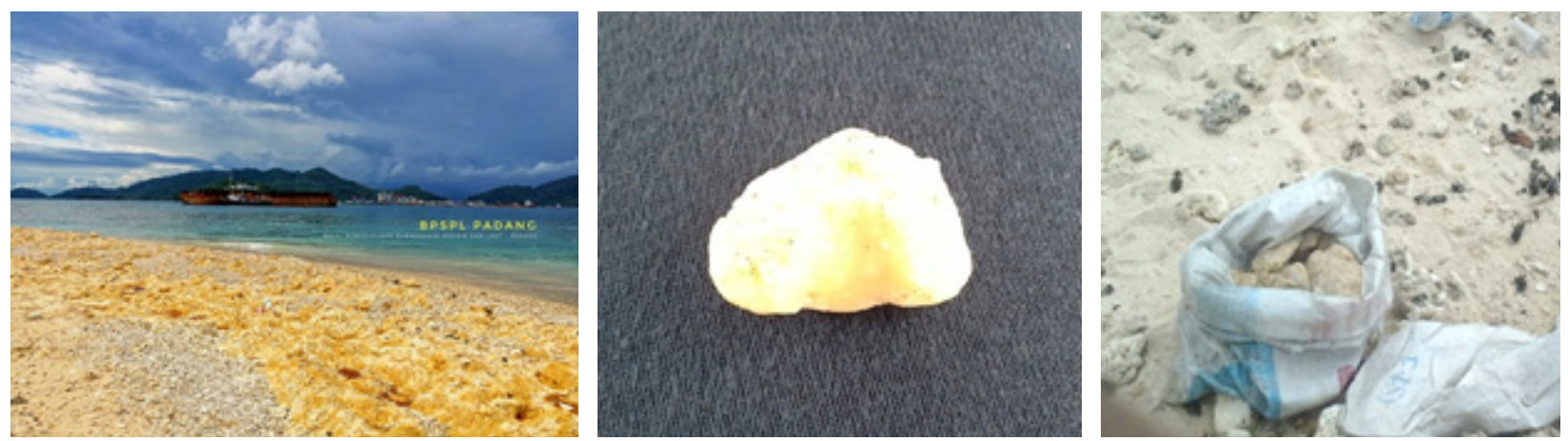

Gambar 1. Karakteristik CPO di kawasan pesisir Teluk Bayur dan Pulau Pasie Gadang.

Sumber: dokumentasi pribadi, 2017

Figure 1. Characteristic of CPO at Bayur Bay and Pasie Gadang Island.

JURNAL KELAUTAN NASIONAL, Vol. 15, No 1, April 2020, Hal. 37-44 


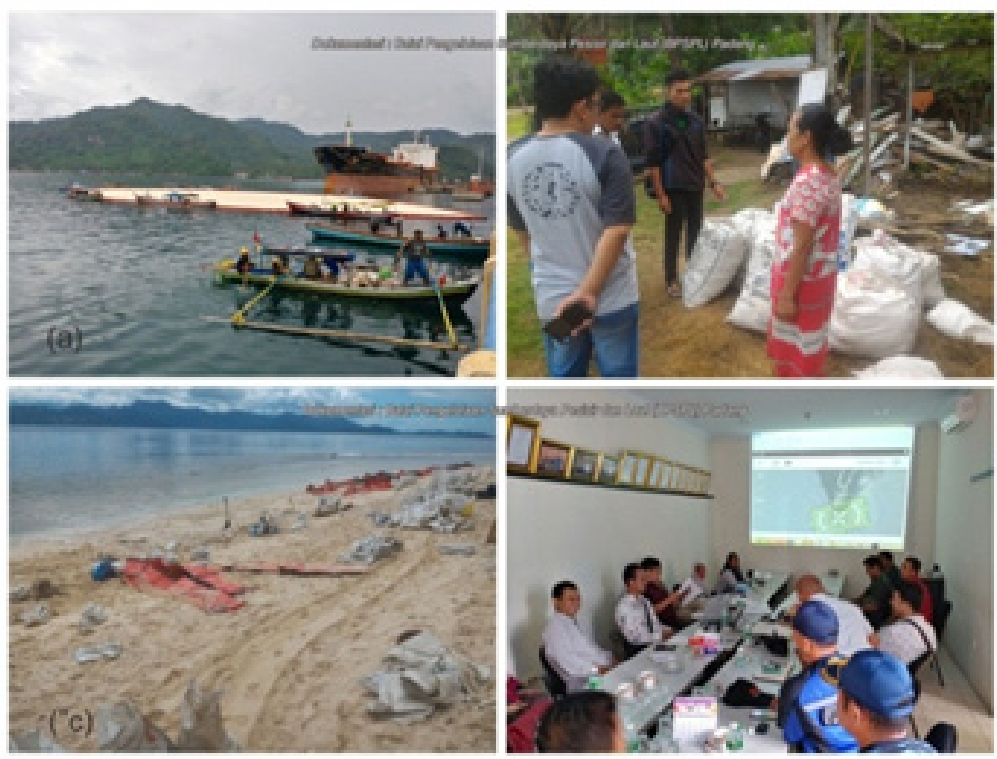

Gambar 2. CPO yang tumpah di perairan Teluk Bayur dan upaya masyarakat bersama instansi terkait untuk membersihkan tumpahan CPO. Sumber: BPSPL, 2017

Figure 2. The spill of CPO at Bayur Bay and the process to clean the waters by the company, local community and related institutions.

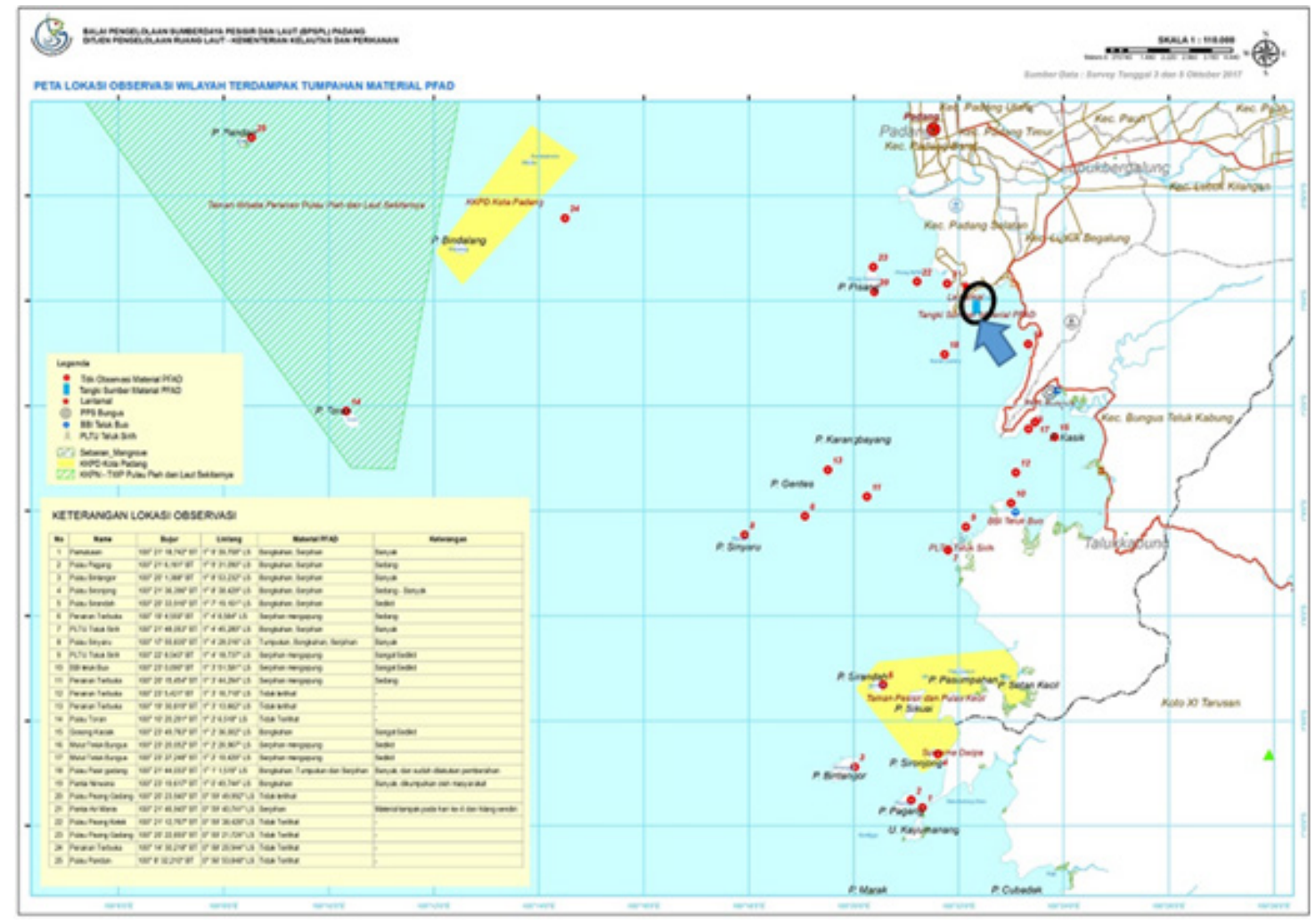

Gambar 3. Lokasi tangki CPO yang bocor dan titik-titik pengamatan sebaran CPO.

Sumber: BPSPL, 2017

Figure 3. The location of CPO leak tank (initial CPO spill) and observation points of CPO spill distribution. 


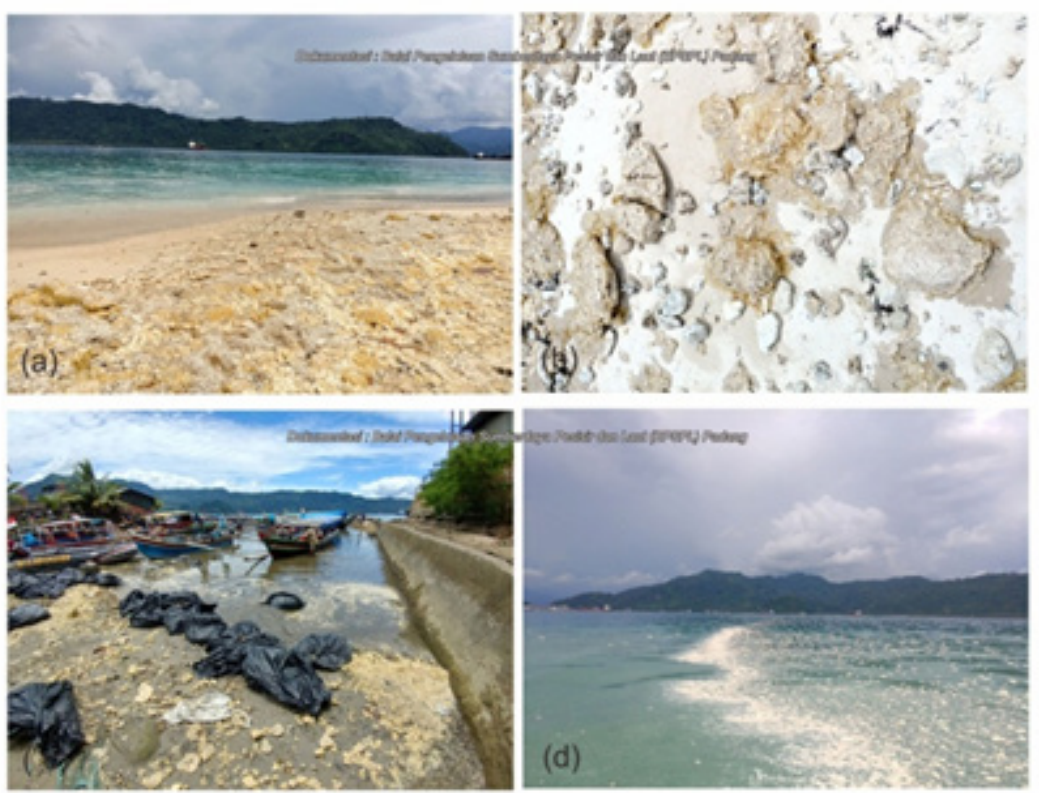

Gambar 4. CPO yang Tumpah di Perairan dan Pesisir Teluk Bayur Setelah Beberapa Hari. Sumber: BPSPL, 2017

Figure 4. The CPO spill at Bayur Bay after few days (more than 2 days)

untuk biota laut. CPO tidak hanya mengapung terbawa arus tetapi juga sebagian besar terdampar di kawasan pesisir pulau-pulau kecil seperti P. Kasik, P. Pasie Gadang dan Gosong Gentes. Pulau kecil yang paling terdampak di lokasi survey adalah P. Pasie Gadang. Beberapa pulau kecil tersebut tidak berpenghuni sehingga tidak terlalu berdampak pada masyarakat walaupun di beberapa lokasi cukup rawan seperti kawasan keramba udang dan lokasi pemancingan di Pulau Sironjong. Hasil lab beberapa parameter kualitas air di Pulau Sirandah dan Pulau Pamutusan tidak memenuhi baku mutu berdasarkan Keputusan Menteri Lingkungan Hidup No.51 Tahun 2004 untuk biota laut seperti rendahnya DO: $0,55-3,99 \mathrm{mg} / \mathrm{L}(<5 \mathrm{mg} / \mathrm{L})$ dan BOD: $0,39-0,48 \mathrm{mg} / \mathrm{L}(<20 \mathrm{mg} / \mathrm{L})$; tingginya kadar COD: $121-180 \mathrm{mg} / \mathrm{L}(>100 \mathrm{mg} / \mathrm{L})$ dan minyak lemak: $1,4-6,6 \mathrm{mg} / \mathrm{L}(>1 \mathrm{mg} / \mathrm{L})$.

CPO yang mengendap di pantai setelah beberapa hari ( $>2$ hari) berbentuk gumpalan-gumpalan yang agak mengeras berwarna kuning jingga, dengan tekstur permukaan lembut dan licin, seperti mentega dan bercampur dengan pasir atau material pantai. Pada radius $10 \mathrm{~m}$ terdapat gumpalan $\mathrm{CPO}$ dengan berat $7,5 \mathrm{~kg}$ dan volume $0,02 \mathrm{~m}^{3}$ atau berat jenis $3,75 \mathrm{gr} /$ $\mathrm{cm}^{3}$. Kontur pantai yang berundak dengan tinggi pasut sekitar 0,5 - $1 \mathrm{~m}$ membuat gumpalan CPO lebih mudah terdampar dan mengendap sehingga menyebabkan polusi di kawasan pesisir. CPO yang membebani pesisir berpotensi memicu abrasi jika terjadi gelombang besar atau hujan deras karena berat jenisnya lebih besar dibanding berat jenis pasir dalam kondisi normal $(2,57-$ $\left.2,66 \mathrm{gr} / \mathrm{cm}^{3}\right)$ dan tekstur yang licin sehingga mudah sliding. Selain itu juga mengganggu proses respirasi burung laut, kepiting, ikan, coral dan lain-lain karena kandungan minyak dan lemak yang sifatnya mengikat pasir dan menyumbat saluran pernafasan biota laut. Pada tingkat sebaran yang lebih rapat, gumpalan dan lapisan minyak dapat menyebabkan terhalangnya penetrasi sinar matahari di laut dan berdampak pada terganggunya proses fotosintesis tanaman laut.

Beberapa kasus tumpahan CPO seperti yang terjadi di Sungai Mentayan, Provinsi Kalimantan Tengah menunjukkan dampak negatif pada mangrove Soneratia caseolaris $L$. berupa terhambatnya proses respirasi dan degradasi dinding sel karena CPO yang menempel pada akar dan batang mangove. Dampak negatif pada udang Macrobrachium rosenbegii dikarenakan menurunnya kualitas lingkungan air untuk parameter DHL, BOD, COD, DO, TDS, $\mathrm{pH}$ dan suhu. Pada mangrove dan udang Windu dewasa mereka dapat membentuk sistem pertahanan dan adaptasi dengan membentuk isoenzim esterase (Setyono \& Soetarto, 2008). Kasus lain tumpahan CPO di perairan Dumai dalam rentang waktu 6 tahun (tahun 20092015) berdampak pada penurunan kualitas air dan kematian massal larva udang windu Penaeus monodon. Hasil sampel air laut menunjukkan konsentrasi minyak di air antara 0,13-0,51 mg/L sedangkan pada sedimen 


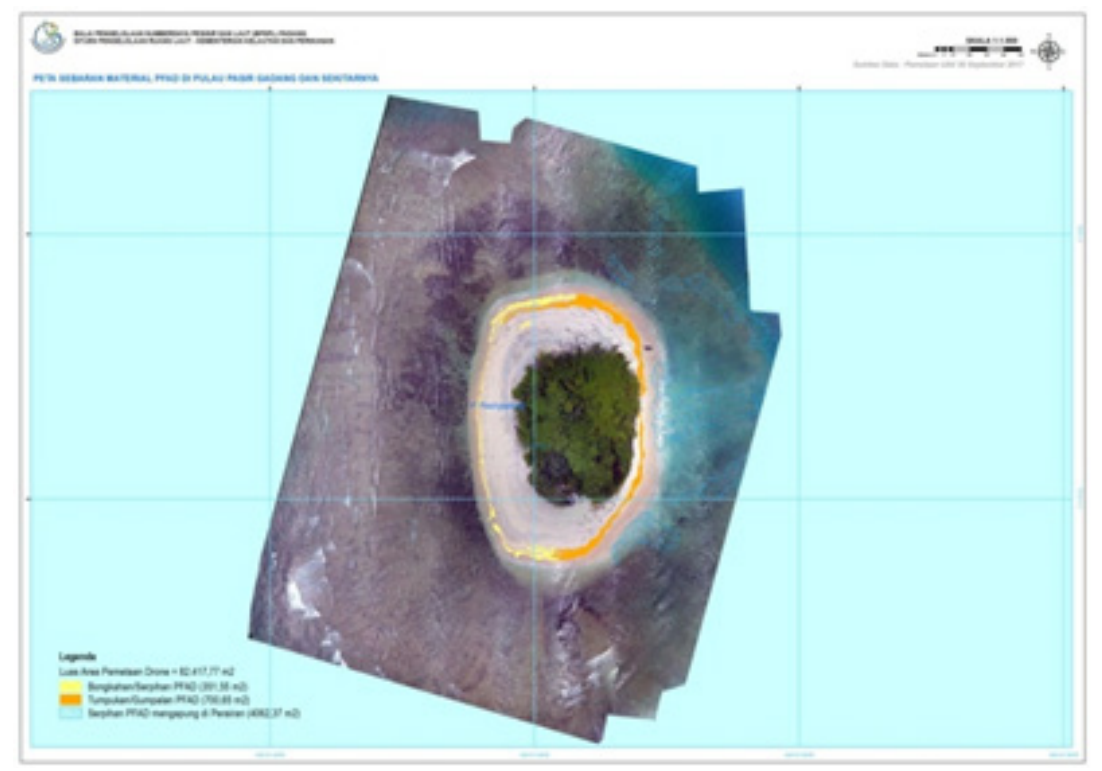

Gambar 5. Luasan Sebaran Tumpahan CPO di Pesisir Pulau Pasie Gadang. Sumber: BPSPL, 2017

Figure 5. The Distribution of CPO spill around the coastal of Pasie Gadang Island.

$0,32-1,51 \mathrm{mg} / \mathrm{Kg}$. Total kematian massal pada larva udang windu Penaeus monodon adalah sebesar 7,50 x $103 \mathrm{mg} / \mathrm{L}$ yang disebabkan gangguan respirasi setelah terpapar CPO selama 2 hari atau 48 jam (Nufus, 2016). Tumpahan minyak juga berdampak negatif pada bentos di dasar perairan dan coral.

CPO yang tersebar hingga Pulau Pasie Gadang memiliki karakteristik berupa serpihan terapung seluas $4.062,37 \mathrm{~m}^{2}$; bongkahan di pantai seluas $351,55 \mathrm{~m}^{2}$; dan gumpalan seluas $700,65 \mathrm{~m}^{2}$ di pesisir seperti pada gambar 5.

Tumpahnya CPO menyebabkan kerugian yang cukup besar bagi perusahaan PT. Wira Inno Mas (PT. WIM) namun demikian perusahaan ini bertanggung jawab dengan bersedia membeli tumpahan $\mathrm{CPO}$ yang dikumpulkan oleh masyarakat sekitar dengan kisaran harga Rp. 7.000,00-Rp. 25.000,00 (tergantung ukuran kantong). Selain itu pihak perusahaan juga melakukan upaya pembersihan lingkungan perairan Teluk Bayur dengan penyedotan menggunakan 2 unit oil boom dan mengumpulkan bongkahan CPO yang terdampar di pesisir pulau-pulau kecil sekitar Teluk Bayur menggunakan kantong-kantong plastik atau kantong ukuran besar secara manual dengan menyewa beberapa penduduk lokal.

Untuk mengatasi degradasi akibat tumpahan CPO, tanaman air seperti Azolla folliculoid merupakan alternatif karena dapat menyerap minyak hingga $5,3 \mathrm{gr} / \mathrm{gr}$ air laut yang tercemar pada suhu optimal $25^{\circ} \mathrm{C}$ dan pH 9 (Amin et al., 2015). Penggunaan konsorsium bakteri (Bacillus licheniformis, Bacillus thermoamylovorans dan Geobacillus pallidus) terbukti menurunkan kadar minyak pada tumpahan minyak bumi (petroleum hidrokarbon) sebesar 77\% dan penurunan toksisitas sebesar $88 \%$ selama 20 hari namun memiliki efek negatif berupa peningkatan turbiditas dan penurunan kadar Oksigen atau DO/ Dissolved Oxygen (Marraskuranto et al., 2012). Pada kondisi normal atau alami diperlukan waktu rata-rata sekitar 5 tahunan pada perairan yang tercemar minyak untuk kembali pulih (Nufus, 2016).

\section{KESIMPULAN DAN SARAN}

Pengukuran parameter kualitas air laut setelah terjadinya tumpahan $\mathrm{CPO}$ menunjukkan hasil yaitu temperatur permukaan air laut sebesar $30,5^{\circ} \mathrm{C} ; \mathrm{pH}$ 5,7; BOD: 0,39-0,48 mg/L, COD: 121-180 mg/L dan minyak lemak: 1,4-6,6 mg/L; serta DO: 0,55$3,99 \mathrm{mg} / \mathrm{L}$. Pada beberapa kasus, tumpahan CPO selain menaikkan temperatur, $\mathrm{pH}, \mathrm{BOD}, \mathrm{COD}$ dan turbiditas; juga mengurangi kadar DO dan TDS. Dampak negatif tumpahan CPO berpengaruh pada mangrove, udang Windu, kepiting, coral dan lain-lain karena mengganggu proses respirasi dan fotosintesis. Beberapa cara untuk mengurangi kadar minyak CPO yang terlanjur mencemari perairan selain Oil Boom dan Oil sponge juga dapat menggunakan tanaman air seperti Azolla folliculoid dan bakteri tertentu jenis Bacillus dan Geobacillus. Walaupun pihak perusahaan 


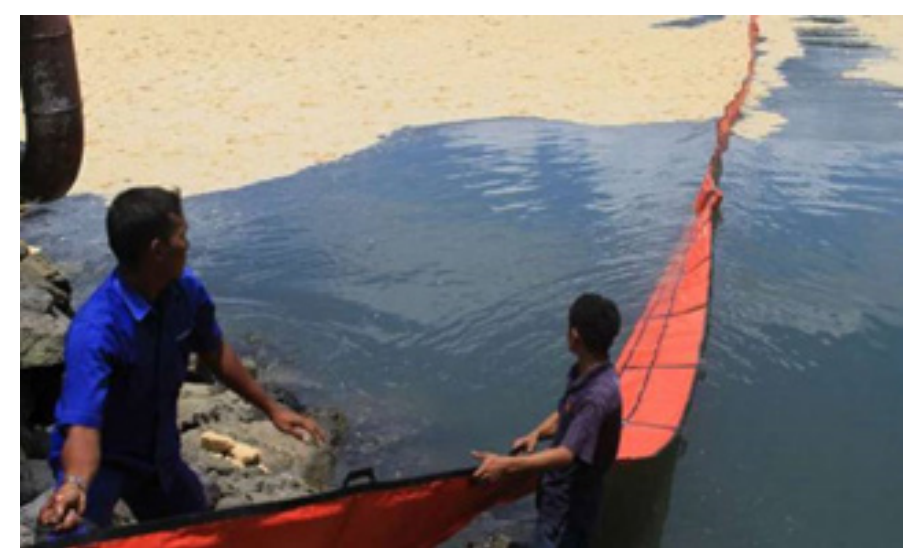

Gambar 6. Penyedotan Tumpahan CPO di laut menggunakan Oil Boom oleh PT. WIM.

Sumber: www.viva.co.id

Figure 6. The handling of CPO spill on waters using Oil Boom by WIM Company.

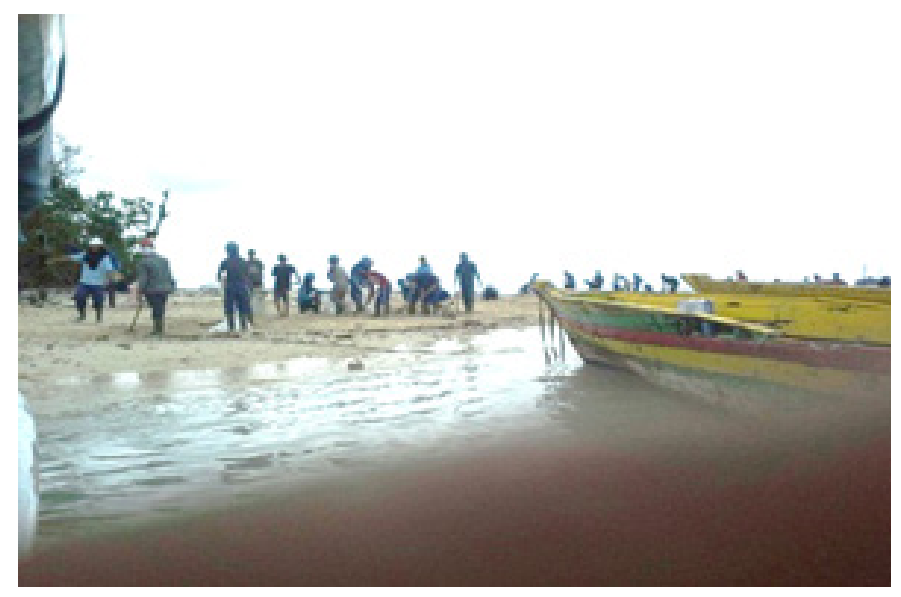

Gambar 7. Pembersihan Tumpahan CPO oleh PT. WIM di Pulau Pasie Gadang.

Sumber: dokumentasi pribadi

Figure 7. The coastal cleaning of CPO spill by WIM Company at Pasie Gadang Island.

sudah bertanggung jawab, namun tetap diperlukan kewaspadaan dan mitigasi bencana terhadap tumpahan minyak CPO untuk meminimalkan resiko degradasi lingkungan.

\section{UCAPAN TERIMA KASIH}

Ucapan terimakasih kami ucapkan kepada semia pihak atas terlaksananya seluruh kegiatan penelitian sampai selesai.

\section{DAFTAR PUSTAKA}

Amal Fatullah Randy. (2009). Pemetaan Indeks Kepekaan Lingkungan Terhadap Tumpahan Minyak di Pesisir Pulau Pramuka, Panggang, Semak Daun dan Karang Congkak, Kepulauan Seribu, Jakarta. Prodi Ilmu dan Teknologi Kelautan. Fakultas Perikanan dan Ilmu Kelautan. IPB.

Amin, J. A., Abkenar, M. V., \& Zendehboudi, S. (2012).
Natural Sorbent for Oil Spill Cleanup from Water Surface: Environmental Implication Department of Chemical Engineering, University of Guilan, Rasht, 41996-13769, Iran. Department of Chemical Engineering, Massachusetts Institute of Technology, Cambridge, Massachusetts 02139, United States. Ind. Eng. Chem. Res. 54(43), 10615-10621.

Barus, A., Tanjung, A., \& Ghalib, M. (2017). Pola Arus Pasang Surut dan Gelombang di Perairan Teluk Bayur Kota Padang Provinsi Sumatera Barat. Jurnal Online Mahasiswa Vol.4 No.1.Fakultas Perikanan dan Ilmu Kelautan. Universitas Riau. Diakses Juli 2018 dari https://jom.unri.ac.id/index.php/JOMFAPERIKA/ article/view/13455.

BPSPL. (2017). BPSPL Padang Observasi Dampak Tumpahan Minyak FAD. Diakses 10 Oktober 2017 dari http://bpsplpadang.kkp.go.id/bpspl-padangobservasi-dampak-tumpahan-minyak-pfad.

Charles, N. Nwoko. (2014). Assessing The Sosioeconomic Impacts Arising From Oil Pollutions in The Niger Delta Region of Nigeria: Including Proposals for Solution. Environmental Law and Mangement. 
22 August 2014. Doctoral Dissertations. Aalto University. School of Engineering, Real Estate, Planning and Geoinformatics. http://urn.fi/ URN:ISBN:978-952-60-5799-6. Finland. DOI: 10.1021/acs.iecr.5b01715. http://pubs.acs.org/doi/ pdfplus/10.1021/acs.iecr.5b01715.

Fadhilat, L. (2007). Penentuan Lokasi yang Rentan terhadap Tumpahan Minyak di Ekosistem Mangrove Segara Anakan, Cilacap, Jawa Tengah Berdasarkan Pendekatan Cell Based Modelling. Skripsi. Prodi Ilmu dan Teknologi Kelautan. IPB.

Keputusan Menteri Lingkungan Hidup no.51 Tahun 2004 tentang Penetapan Baku Mutu Air Laut. Jakarta.

Marraskuranto, E., Januar, H. I., \& Pratitis, A. (2012). Application of Micro Morr E-3360 as Bioremediation Material for Marine Oil Spill. JPB Perikanan, 7(2), 97-104.

Manafi, M. R. (2010). Rancang Bangun Pengelolaan Pulaupulau Kecil Berbasis Pemanfaatan Ruang (Khusus Gugus Pulau Kaledupa, Kabupaten Wakatobi). Disertasi. Sekolah Pascasarjana IPB. Bogor.

Mutmainnah. (2012). Kajian Model Kesesuaian Pemanfaatan Sumberdaya Pulau-pulau Kecil Berbasis Kerentanan dan Daya Dukung di Kecamatan Liukang Tupabbiring, Kabupaten Pangkajene Kepulauan, Provinsi Sulawesi Selatan. Tesis. Sekolah Pasca Sarjana Institut Pertanian Bogor.

Nufus, H. (2016). Potensi Pencemaran Minyak Sawit Kasar (CPO) di Perairan Umum Dumai dan Toksisitas Akut Terhadap Organisme. Januari 2016. Tesis Sekolah Pasca Sarjana IPB. Bogor.

Rahmadhani. (2017). 50 Ton Minyak Sawit Mentah Tumpah ke Teluk Bayur. Diakses 30 September 2017 dari http://regional.kompas.com/ $\mathrm{read} / 2017 / 09 / 29 / 18194881 / 50$-ton-minyak-sawitmentah-tumpah-ke-teluk-bayur.

Safitri, R. (2009). Model Sebaran Tumpahan Minyak di Alur Pelayaran Pelabuhan Tanjung Intan Cilacap, Jawa Tengah. Skripsi. Prodi Ilmu dan Teknologi Kelautan IPB. Bogor.

Setyono, P., \& Soetarto, E. S. (2008). Biomonitoring Degradasi Ekosistem Akibat Limbah CPO di Muara Sungai Mentayan Kalimantan Tengah dengan Metode Elektromorf Isozim Esterase. BIODIVERSITAS, 9(3). ISSN: 1412-033X. DOI: 10.13057/biodiv/d090317. UGM. Yogyakarta.

Suhery, N., Damar, A., \& Effendi, H. (2017). Indeks Kerentanan Ekosistem Terumbu Karang Terhadap Tumpahan Minyak: Kasus Pulau Pramuka dan Pulau Belanda di Kepulauan Seribu. Jurnal Ilmu dan Teknologi Kelautan Tropis. 9(1), 67-90.

Tim Jawa Pos. (2017). CPO Tumpah ke Laut, Perairan Teluk Bayur Tercemar. Diakses 30 September 2017 dari https://www.jawapos.com/read/2017/09/29/159882/ cpo-tumpah-ke-laut-perairan-pelabuhan-telukbayur-tercemar.

Tim Viva. (2017). Lima Puluh Ton Minyak Sawit Tumpah di
Teluk Bayur. Diakses 30 September 2017 dari http:// www.viva.co.id/berita/nasional/961412-lima-puluhton-minyak-sawit-tumpah-di-teluk-bayur.

Tondobala, L. (2011). Pendekatan untuk Menentukan Kawasan Rawan Bencana di Pulau Sulawesi. Jurnal Sabua, 3(3), 40-52. ISSN 2085-7020. PWK FT Universitas Sam Ratulangi. Manado.

Udoh, J. C., \& Ekanem, E. M. (2011). GIS Based Risk Assessment of Oil Spill in The Coastal Areas of Akwa Ibom State, Nigeria. African Journal of Environmental Science and Technology, 5(3), pp: 205-211, March 2011. ISSN 1996-0786X@2011 Academic Journals. http://www.academicjournals.org/AJEST.

Wibowo, M. (2009). Pemetaan Tingkat Kepekaan Lingkungan Pesisir di Kota Semarang. Jurnal Hidrosfir Indonesia, 4(1), 17-22. 
